\title{
Modifikasi Perangkat Tolak Peluru dalam Olahraga Tolak Peluru Anak Tunagrahita
}

\author{
Vrenora Prima Yova, Dimas Arif Dewantoro \\ Universitas Negeri Malang \\ E-mail: vrenorayova@gmail.com
}

\begin{abstract}
Abstrak: Olahraga tolak peluru menggunakan media peluru berbahan besi sehingga media tersebut sangat berat digunakan oleh siswa tunagrahita. Untuk mencapai pembelajaran siswa tunagrahita maka perlu modifikasi peluru menggunakan bahan karet. penelitian ini menggunakan kuantitatif, desain Quasi Experiment model One Group Pretest-Posttest Design. Teknik analisis data yang digunakan dalam penelitian adalah analisis deskriptif dengan uji hipotesis Wilcoxon. Hasil analisis data yang diketahui hasil perhitungan tabel $\mathrm{T}_{\text {hitung }}$ sebesar 0 sedangkan pada $\mathrm{T}_{\text {tabel }}$ dengan $(\alpha 0,05$ dan $\mathrm{n}=6)=2$. Berdasarkan hasil pengujian, maka $\mathrm{H}_{0}$ ditolak dan $\mathrm{H}_{1}$ diterima. Hasil analisis terdapat perbedaan nilai dapat disimpulkan modifikasi peluru berpengaruh terhadap ketrampilan tolak peluru siswa tunagrahita kelas XI SMALB Yayasan Putra Pancasila Malang.

Kata Kunci: Ketrampilan Tolak Peluru, Modifikasi Peluru, Tunagrahita

Abstract : Sport shot put bullets made of iron using the media so that the media is very heavily used by students with intellectual disability. To achieve the students with intellectual disability learning, it is necessary to modify the bullet using a rubber material. This study used a quantitative, desain Quasi Experiment with One Group Pretest-Posttest Design. Data analysis techniques used in this research was descriptive analysis with Wilcoxon hypothesis test. The results of data analysis known $\mathrm{T}_{\text {count }}$ calculation results at 0 while in $\mathrm{T}_{\text {table }}$ with $(\alpha 0.05$ and $\mathrm{n}=6)=2$. Based on test results, then $\mathrm{H} 0$ was rejected and $\mathrm{H} 1$ was accepted. The results of the analysis can be concluded there was a difference value modification of bullets shot put skills affect the class XI students with intellectual disability SMALB Yayasan Pancasila Putra Malang.
\end{abstract}

Keywords : Shot put skills, Bullet modification, Intellectual Disability

Pendidikan jasmani merupakan aspek ketrampilan dasar dalam olahraga dengan melalui pendidikan jasmani di harapkan dapat merangsang perkembangan dan pertumbuhan jasmani anak baik emosi, mental, sosial dan ketrampilan gerak anak. Proses pembelajaran pendidikan jasmani ada peran guru atau pelatih yang diharpkan mengajarkan berbagai ketrampilan olahraga berupa gerak dasar, teknik dan strategi permainan serta kebiasaan pola hidup sehat. Menurut Sudianto (2005) pendidikan jasmani yaitu meliputi kebugaran fisik, pengembangan ketrampilan motorik, dan perkembangan kognitif serta perkembangan afektif. Jadi, pembelajaran pendidikan jasmani mempunyai ranah yang luas untuk perkembangan diri pada siswa, peran guru sangat penting untuk membantu melatih supaya siswa dapat tumbuh dan berkembang melalui olahraga.

Pendidikan jasmani adaptif merupakan pendidikan mengenai hal kebugaran jasmani yang diberikan untuk anak berkebutuhan khusus. Ada tiga program utama yang diberikan dalam perkembangan menurut French dan Jansme (1982) yaitu a) pendidikan jasmani disesuaikan melalui program aktivitas jasmani tradisional yang di modifikasi untuk memungkinkan individu dengan kelainan memperoleh kesempatan untuk untuk berpartisipasi dengan aman, sukses, dan memperoleh kepuasan. b) pendidikan jasmani korektif terutama mengacu pada kelainan fungsi postur dan mekanika tubuh. c) pendidikan jasmani yang mengacu pada perkembangan kesegaran jasmani yang progresif atau latihan otot-otot besar untuk meningkatkan kemampuan jasmani individu sampai pada tingkat atau mendekati tingkat kemampuan teman sebaya.

Permasalahan yang ada saat ini terutama pada anak berkebutuhan khusus yaitu anak tunagrahita mereka cenderung memiliki sifat yang suka berdiam diri, kurang menyukai olahraga dan merasa mudah lelah. Dalam menginkatkan keaktifan anak tunagrahita, guru harus mempuyai banyak cara kreatif dalam menciptakan suatu olahraga agar siswa lebih tertarik. Salah satunya dengan olahraga tolak peluru yang menggunakan media modifikasi peluru.

Model pembelajaran tolak peluru dilakukan sebagian besar selama ini masih terlihat monoton dengan sarana prasarana yang sesungguhnya serta belum memperhatikan media pembelajaran yang dimiliki sekolah. Dalam mempraktikkan materi tolak peluru yang akan diberikan tentu dapat membuat siswa bosan dan pada akhirnya siswa tidak memperhatikan apa yang disampaikan oleh guru.

Media merupakan hal utama yang harus digunakan dalam suatu pembelajaran baik di dalam maupun di luar kelas seperti olahraga. Untuk anak berkebutuhan khusus perlu adanya suatu modifikasi media yang digunakan untuk menarik perhatian siswa dan juga untuk membantu siswa dalam mencapai suatu pembelajaran. 
Anak berkebutuhan khusus yaitu anak yang mengalami hambatan baik dari segi fisik, mental, dan emosi. Hambatan tersebut terjadi di dalam proses perkembangan bila di bandingankan dengan anak-anak lain seusianya. Sehingga anak berkebutuhan khusus memerlukan layanan pendidikan secara khusus.

Anak tunagrahita merupakan anak yang mempunyai hambatan dan intelektual dibawah rata-rata mereka juga memiliki hambatan dalam menyesuaikan diri dengan lingkuangan (Septiani. 2015).sedangkan menurut Efendi (2006) seseorang dikategorikan berkelainan mental subnormal atau tunagrahita, jika ia memiliki tingkat kecerdasan yang sedemikian rendahnya atau dibawah normal sehingga untuk meniti tugas perkembangannya memerlukan bantuan atau layanan secara spesifik termasuk dalamprogram pendidikan pendidikannya. Sehingga dalam melakukan olahragapun anak tungrahita juga memerlukan bimbingan dan bantuan guru.

Tolak peluru merupakan olahraga cabang atletik menggunakan media peluru. Menurut Kencana (2015) tolak peluru merupakan suatu koordinasi gerak menolak yang eksplosif, karena dalam gerak tersebut dibutuhkan pengerahan kekuatan yang penuh disertai dengan kecepatan. Kedua unsur tersebut adalah membentuk power. Untuk mendapatkan hasil yang jauh dari suatu gerakan tolak peluru maka membutuhkan power lengan yang besar.

Peluru merupakan media utama yang digunakan dalam olahraga tolak peluru. Ukuran peluru antara putra dan putri mempunyai perbedaan . Menurut Mahardika (2013) peluru yang terbuat dari bahan besi yang mempunyai berat antara $3 \mathrm{~kg}$ untuk putri dan $5 \mathrm{~kg}$ untuk putra. Sedangkan menurut IAAF (2013) dalam Saputri (2016) peluru yang digunakan dalam tolak peluru dari bahan besi yaitu untuk putri $3 \mathrm{~kg}$, $4 \mathrm{~kg}$, dan putra $5 \mathrm{~kg}$, 6kg, dan $7 \mathrm{~kg}$.

Dalam mencapai pembelajaran olahraga tolak peluru pada anak tunagrahita tentunya dengan menggunakan media peluru yang terbuat dari bahan besi siswa akan merasa berat dan mudah lelah sehingga perlu adanya modifikasi peluru. Dalam penelitian ini tolak peluru yang akan diberikan kepada anak tunagrahita yaitu dengan menggunakan modifikasi peluru berbahan dasar karet. peluru yang dimodifikasi dari bahan karet juga memiliki ukuran dan beratm tetapi berbeda dengan peluru aslinya dari bahan besi. Modifikasi peluru dari karet dapat digunakan dalam pembelajaran tolak peluru karena dari segi bentuk dan fungsi yang sama. Dengan media modifikasi peluru dari bahan karet ini juga tidak begitu membahayakan siswa karena beratnya lebih ringan dibandingkan dengan peluru besi.

Berdasarkan permasalahan di atas, dalam melakukan olahraga tolak peluru perlu menggunakan media peluru yang tebuat dari bahan karet supaya anak tidak merasa cepat lelah dan keberatan. Dengan adanya modifikasi peluru diharapkan dapat membantu dalam mencapai pembelajaran ketrampilan tolak peluru siswa kelas XI SMALB Yayasan Putra Pancasila Malang.

\section{METODE}

Metode dalam penelitian ini menggunakan jenis penelitian eksperimen. Penelitian ini bertujuan untuk mengetahui pengaruh modifikasi peluru terhadap ketrampilan tolak peluru pada siswa tunagrahita kelas XI SMALB Yayasan Putra Pancasila Malang. dalam penelkitian ini menggunakan pendekatan kuantitatif berjenis eksperimen semu tipe One Group pretest posttest dengan pengamatan langsung terhadap satu kelompok subjek tanpa adanya kelompok pembanding atau kelompok kontrol (Sugiono, 2016).

Penelitian yang dilakukan untuk mendapatkan hasil tes sebelum dan sesudah diberikan perlakuan yang akan dibandingkan untuk melihat apakah variabel bebas berpengaruh terhadap variabel terikat. Adapun gambar desain penelitian sebagai berikut :

Gambar 1. Desain Penelitian

$$
\mathrm{O}_{1} \times \mathrm{O}_{2}
$$

Keterangan :
$\mathrm{O}_{1}$ : Nilai Pretest
$\mathrm{X}:$ perlakuan atau treatment
$\mathrm{O}_{2}$ : Nilai Posttest
Sugiono, $(2016)$

Subyek dalam penelitian ini adalah seluruh siswa tunagrahita kelas XI SMALB Yayasan Putra Pancasila Malang pada tahun ajaran 2018/2019. Dengan jumlah sampel yang digunakan sebanyak 6 siswa.

Variabel dalam penelitian ini terdiri atas variabel bebas dan variabel terikat. Variabel bebas dari penelitian ini adalah modifikasi peluru dan variabel terikat dalam penelitian ini adalah ketrampilan tolak peluru. Instrument dalam penelitian ini adalah menggunakan jenis tes yaitu untuk mengukur pre-test dan post-test. 
Tabel 1. Kriteria Validitas

\begin{tabular}{ccl}
\hline No. & $\begin{array}{c}\text { Kriteria pencapaian } \\
\text { nilai } \\
\text { (Keefektifan) }\end{array}$ & \\
\hline 1 & $81,00 \%-100,00 \%$ & $\begin{array}{l}\text { Sangat valid, sangat efektif, sangat tuntas, dapat digunakan tanpa } \\
\text { perbaikan. }\end{array}$ \\
2 & $61,00 \%-80,00 \%$ & $\begin{array}{l}\text { Cukup valid, cukup efektif, cukup tuntas, dapat digunakan namun perlu } \\
\text { perbaikan kecil. }\end{array}$ \\
3 & $41,00 \%-60,00 \%$ & $\begin{array}{l}\text { Kurang valid, kurang efektif, atau kurang tuntas, perlu perbaikan besar, } \\
\text { disarankan tidak dipergunakan. } \\
\text { Tidak valid, tidak efektif, tidak tuntas, tidak bisa digunakan. } \\
4\end{array}$ \\
$21,00 \%-40,00 \%$ & $\begin{array}{l}\text { Sangat tidak valid, sangat tidak efektif, sangat tidak tuntas, tidak bisa } \\
\text { digunakan. }\end{array}$ \\
\hline 5 & $00,00 \%-20,00 \%$ \\
\hline
\end{tabular}

Sumber : (Akbar,2017:82)

Tabel 2. Hasil Pretest Ketrampilan Tolak Peluru

\begin{tabular}{|c|c|c|}
\hline No. & Nama & Nilai \\
\hline 1. & FN & 55 \\
\hline 2. & NI & 51 \\
\hline 3. & $\mathrm{RN}$ & 55 \\
\hline 4. & RL & 47 \\
\hline 5. & IN & 50 \\
\hline 6. & UA & 52 \\
\hline & Jumlah & 310 \\
\hline & Rata - rata & 51,6 \\
\hline
\end{tabular}

Tabel 3. Hasil Posttest Ketrampilan Tolak Peluru

\begin{tabular}{llc}
\hline No. & Nama & Nilai \\
\hline 1. & FN & 77 \\
2. & NI & 72 \\
3. & RN & 79 \\
4. & RL & 68 \\
5. & IN & 73 \\
6. & UA & 70 \\
\hline & Jumlah & 439 \\
\hline & Rata - rata & 73,2 \\
\hline
\end{tabular}

Teknik analisis data yang dilakukan dengan melakukan ketrampilan tolak peluru yang diperoleh dari hasil pre-test dan post-test yang selanjutnya di lakukan uji validitas dan reabilitas tes. Analisis data digunakan untuk menjawab rumususan masalah atau menguji hipotesis yang telah dirumuskan dalam proposal (Sugiono, 2016). Dalam penelitian ini menggunakan statistik nonparametrik karena subjek yang akan di teliti hanya 6 siswa. Adapun analisis yang dilakukan yaitu uji hipotesis. Hipotesis merupakan jawaban sementara terhadap rumusan dalam penelitian, di mana rumusan masalah dalam penelitian ini telah dinyatakan dengan bentuk kalimat pertanyaan (Sugiono, 2016).
Uji hipotesis pada penelitian ini menggunakan uji Wilcoxon Signed Rank.

\section{HASIL DAN PEMBAHASAN}

\section{Hasil}

Penelitian ini dilaksanakan pada siswa kelas XI SMALB Yayasan Putra Pancasila Malang. melalui teknik pengambilan data dengan menggunakan subjek sebanyak 6 siswa. Berdasarkan tabel di atas dapat di ketahui hasil pre-test ketrampilan tolak peluru sebelum diberikan perlakuan atau treatment memiliki nilai tertinggi 55 dan nilai terendah 47 dengan nilai ratarata hitung 51,6. Setelah selesai melakukan treatment, peserta didikdiberikan posttest. Berikut data hasil posttest kemampuan melakukan tolak peluru setelah diberikan perlakuan.

Berdasarkan tabel di atas dapat diketahui hasil post-test ketrampilan tolak peluru setelah diberikan perlakuan atau treatment memiliki hasil nilai tertinggi 79 dan nilai terendah 68 dengan nilai rata-rata 73,2. Setelah mengetahui hasil pretest dan posttest pada penyajian data, maka dapat dilakukan rekapitulasi perbandingan nilai.

Dari data yang telah disajikan dapat disimpulkan nilai rata-rata hasil posttest lebih tinggi dari nilai pretest. Perbedaan tersebut dapat menunjukkan adanya perbedaan keketrampilan tolak peluru sebelum dan setelah diberikan perlakuan. Dalam uji hipotesis dapat dikatakan bahwa, jika $\mathrm{T}_{\text {hitung }}>\mathrm{T}_{\text {tabel }}$ maka $\mathrm{H}_{\mathrm{o}}$ diterima sedangkan jika $\mathrm{T}_{\text {hitung }}<\mathrm{T}_{\text {tabel }}$ maka $\mathrm{H}_{\mathrm{o}}$ ditolak.

Berdasarkan hasil perhitungan pada tabel di atas, diperoleh $\mathrm{T}_{\text {hitung }}$ sebesar 0 sedangkan pada $\mathrm{T}_{\text {tabel }}$ dengan $(\alpha 0,05$ dan $n=6)=2$. Berdasarkan hasil pengujian, maka hipotesis diterima karena $\mathrm{T}_{\text {hitung }}<\mathrm{T}_{\text {tabel }}$ dapat diartikan bahwa $\mathrm{T}_{\text {hitung }}=0<\mathrm{T}_{\text {tabel }}=2$ dari hasil tersebut di nyatakan bahwa $\mathrm{H}_{0}$ ditolak dan $\mathrm{H}_{1}$ diterima. 
Tabel 4. Perbandingan Hasil Nilai Pretest Dan Posttest

\begin{tabular}{llcc}
\hline No. & Nama & $\begin{array}{c}\text { Nilai Pre- } \\
\text { test }\end{array}$ & Nilai Post-test \\
\hline 1. & FN & 55 & 77 \\
2. & NI & 51 & 72 \\
3. & RN & 55 & 79 \\
4. & RL & 47 & 68 \\
5. & IN & 50 & 73 \\
6. & UA & 52 & 70
\end{tabular}

\begin{tabular}{lcc}
\hline Jumlah & 310 & 439 \\
\hline Rata - rata & 51,6 & 73,2 \\
\hline
\end{tabular}

Tabel 5. Uji Hipotesis Dengan Uji Wilcoxon

\begin{tabular}{lllllll}
\hline & & Nilai & & Rank & $\begin{array}{c}\text { Tanda negatif } \\
(-)\end{array}$ \\
\hline 1. & 55 & 77 & 22 & 3 & +3 & \\
2. & 51 & 72 & 21 & 2,5 & $+2,5$ & \\
3. & 55 & 79 & 24 & 5 & +5 & \\
4. & 47 & 68 & 21 & & $+2,5$ & \\
5. & 50 & 73 & 23 & 2,5 & +4 & \\
6. & 52 & 70 & 18 & 4 & +1 & \\
& & & & 1 & & \\
\hline
\end{tabular}

Dari hasil analisis diketahui bahwa terdapat perbedaan nilai positif antara pre-test dan post-test sehingga dapat disimpulkan bahwa modifikasi peluru berpengaruh terhadap ketrampilan tolak peluru siswa tunagrahita kelas XI SMALB Yayasan Putra Pancasila Malang.

\section{Pembahasan}

Sebelum diberikan perlakuan peneliti memberikan pretest terlebih dahulu dengan menggunakan media berupa peluru besi berukuran $1 \mathrm{~kg}$. Siswa merasa keberatan dan mudah lelah saat melakukan tolak peluru dengan hal tersebut maka nilai rata-rata yang di peroleh sebesar 51,6. Selama. Pelaksanaan pretest terdapat siswa yang mengalami hambatan dalam motorik kasar sehingga tidak dapat dengan maksimal saat melakukan gerak tubuh dan tolakan, ketika berada di dalam lingkaran lapangan siswa terlihat pasif. Maka dari itu, sebelum dilakukannya posttest perlu adanya treatment untuk melatih gerak dalam ketrampilan tolak peluru.

Menurut Pradani (2014) menyatakan bahwa gerakan yang timbul dan terjadi pada motorik kasar merupakan gerakan yang terjadi dan melibatkan otot-otot besar dari bagian tubuh, dan memerlukan tenaga yang cukup besar. Dari uraian di atas dapat disimpulkan motorik kasar adalah aktivitas gerak yang memerlukan otot- otot besar dalam koordinasi tubuh. Sehingga dalam melakukan olahraga tolak peluru hal utama yang dilakukan yaitu gerak tubuh siswa. Setelah dilakukan treatmant atau perlakuan menggunakan media modifikasi peluru, maka dapat melaksanakan posttest sebagai pengukuran dalam penelitian. Berdasarkan hasil nilai posttest ketrampilan tolak peluru gaya ortodoks dan gaya O'brien di peroleh nilai rata-rata 73,2 .

Dalam pelaksaan treatmant, peneliti memberikan pelatihan kepada siswa ketrampilan tolak peluru dengan dua jenis gaya yaitu gaya ortodoks dan gaya O'brien dengan menggunakan media peluru berbahan dasar karet. Menurut Bahagia(2010) dalam Susanto (2014) Modifikasi yaitu menganalisis dan mengembangkan suatu materi atau media pembelajaran dalam bentuk aktivitas belajar yang berpotensi sehingga dapat mempelancar siswa dalam proses belajar.dengan menggunakan media peluru berbahan karet dapat membuat siswa lebih semangat dalam latihan tolak peluru karena siswa tunagrahita merasa tidak keberatan dan tidak cepat lelah. Setelah dilakukan treatment ketrampilan tolak peluru gaya ortodoks dan gaya O'brien dengan menggunakan media modifikasi peluru berbahan dasar karet kemudian peneliti melakukan posttest kepada siswa sesuai dengan treatment yang telah diberikan dan tanpa bantuan, siswa melakukan dengan sendirinya.

Modifikasi peluru berpengaruh terhadap ketrampilan tolak peluru pada siswa tunagrahita kelas XI SMALB Yayasan Putra Pancasila Malang, hal ini dapat membantu siswa dalam pencapaian suatu pembelajaran olahraga khususnya tolak peluru.

Dalam menggunakan modifikasi peluru berbahan dasar karet membuat pembelajaran olahraga tolak peluru menjadi efektif karena siswa tidak mudah lelah karena beban peluru tidak terlalu berat sehingga tercapainya pembelajaran ketrampilan tolak peluru gaya ortodoks dan gaya O'brien dapat dicapai siswa. Hasil penelitian Menurut Hartini (2015) Penerapan metode modifikasi alat menggunakan bola kasti terbukti dapat meningkatkan hasil belajar siswa dengan olahraga tolak peluru gaya ortodoks. Hal tersebut terbukti adanya peningkatan hasil belajar yang cukup baik. Yaitu pada siklus I dengan nilai rata-rata sebesar 72,59 jadi peningkatannya sebesar 9,22\%. Sedangkan nilai rata-rata siklus II yaitu 80,42 dengan peningkatannya $21,01 \%$ yang dilakukna guru dalam meningkatkan tolak peluru gaya ortodoks telah direncanakan dengan baik sehingga dapat membuat siswa aktif karena didukung oelh adanya motivasi dalam melakukan modifikasi alat dengan menggunakan bola kasti.

Sedangkan menurut Susanto (2014) hasil penelitian menunjukkan bahwa modifikasi peluru 
yang berbahan dasar serbuk gergaji dalam proses pembelajaran pendidikan jasmani terbukti dapat meningkatkan aktivitas jasmani siswa. Siswa terlihat lebih aktif dan ceria dalam mengikuti pembelajaran penjasorkes. Peneliti terdahulu lainnya yaitu Daniati (2014) menyatakan bahwa hasil belajar mengalami peningkatan karena proses pembelajaran melalui modifikasi media pembelajaran terhadap hasil belajar tolak peluru gaya ortodoks. Proses pembelajaran yang diberikan siswa mendapatkan pengalaman serta pemahaman bagaimana gerak yang dilakukan untuk mendapatkan konsep atau pemahaman yang baik dan benar. Dengan modifikasi media, guru dapat memberikan suasana aktivitas yang berbeda dari sebelumnya. Selain itu dengan adanya modifikasi media lebih menekankan keseriusan siswa untuk melakukan teknik tolak peluru dengan benar. Hal lain yang dapat dilihat yaitu dengan nilai yang diperoleh, nilai rata-rata pretest yaitu 21,3 dan nilai rata-rata posttest 37,66, mengalami peningkatan 16,36. Berdasarkan hasil penelitian dan uji pengaruh, terdapat pengaruh modifikasi media pembelajaran terhadap hasil belajar tolak peluru gaya ortodoks di SMPN 2 Capkala.

Penelitian menurut Elanda, dkk (2014) menyatakan bahwa alat modifikasi peluru dari bola plastik untuk pelaksanaan pembelajaran tolak peluru gaya ortodoks mempunyai hasil nilai sebesar 18,75 sebelum diberikan tindakan. Hal tersebut dikategorikan kurang, karena siswa masih kurang dalam memahami materi tentang teknik dasar tolak peluru gaya ortodoks dan melalui penerapan yang berupa teknik untuk meningkatkan kemampuan menggunakan alat modifikasi dan hasil tes rata-rata siswa menjadi 33,84 sehingga dapat disimpulkan bahwa siswa dapat memahami materi teknik dasar tolak peluru gaya ortodoks.

Dalam penelitian mengenai Pengaruh Modifikasi Peluru Terhadap Ketrampilan Tolak Peluru Pada Siswa Tunagrahita Kelas XI SMALB Yayasan Putra Pancasila Malang. terdapat rata-rata nilai pretest yaitu sebesar 51,6 sedangkan rata-rata nilai posttest sebesar 73,2. Berdasarkan hasil penelitian dan nilai yang telah diperoleh bahwa mengalami peningkatan.

\section{KESIMPULAN DAN SARAN}

\section{Kesimpulan}

Berdasarkan analisis hasil penelitian yang telah dilaksanakan oleh peneliti, maka diperoleh kesimpulan bahwa ketrampilan tolak peluru siswa tunagrahita kelas XI SMALB Yayasan Putra Pancasila Malang sebelum diberikan perlakuan mendapatkan nilai terendah sebesar 47 dan nilai tertinggi 55. Berdasarkan nilai tersebut, diperoleh nilai rata-rata 51,6 dan setelah diberikan perlakuan mengalami peningkatan dengan mendapatkan nilai terendah sebesar 68 dan nilai tertinggi 79. Berdasarkan nilai tersebut diperoleh nilai rata-rata 73,2. Berdasarkan hasil tersebut, di peroleh $\mathrm{T}_{\text {hitung }}$ sebesar 0 sedangkan pada $\mathrm{T}_{\text {tabel }}$ dengan $(\alpha 0,05$ dan $n=6)=2$. Dapat disimpulkan bahwa modifikasi peluru berpengaruh terhadap ketrampilan tolak peluru siswa tunagrahita kelas XI SMALB Yayasan Putra Pancasila Malang.

\section{Saran}

Berdasarkan hasil penelitian yang telah dilakukan, dapat dikemukakan saran bahwa dalam mencapai pembelajaran siswa berkebuthan khusus perlu adanya sarana prasarana yang memadai di sekolah dan guru harus lebih kreatif dalam memberikan media pembelajaran supaya siswa lebih tertarik saat belajar dan dapat membantu mencapai pembelajaran. Sedangkan untuk peneliti selanjutnya, penelitian ini dapat di jadikan rujukan dan mempunyai temuan baru dalam membuat modifikasi peluru dan juga media lainnya.

\section{DAFTAR RUJUKAN}

Abdoellah, A. (1996). Pendidikan Jasmani Adaptif. Jakarta: Proyek Pendidikan Tenaga Akademik.

Akbar, S. (2017). Instrumen Perangkat Pembelajaran. Bandung: PT Remaja Rosdakarya

Daniati, N, Eka, S, dan Edi, P. (2014). Pengaruh Media Pembelajaran Bola Tenis Terhadap Hasil Belajar Tolak Peluru Gaya Ortodoks Di SMP. FKIP Untan. (online) (http://jurnal.untan.ac.id/index. php/jpdpb/article/view/5680/6444)

Efendi, M. (2006). Pengantar psikopedagogik anak berkelainan. Jakarta: PT Bumi Aksara

Elanda, K. (2014). Penerapan Teknik Dasar Tolak Peluru Gaya Ortodok Dengan Menggunakan Alat Modifikasi Dari Bola Plastik. FKIP UNTAN (online)( http://jurnal.untan.ac.id/index.php/ jpdpb/article/viewFile/6129/pdf)

Hartini, W.Y.N \& Ahmad, A. (2015). Upaya Meningkatkan Pembelajaran Tolak Peluru Gaya Ortodok's Dengan Media Modifikasi Bola Kasti Di SDN. Universitas Tanjung Pura. Pontianak (online) (http://jurnal.untan.ac.id/index.php/ jpdpb/article/view/9833)

Kencana, I. N.T.P, (2015). Pengaruh Pelatihan Dengan Pemberian BebanPush-Up TerhadapHasilBelajar Tolak Peluru Smp Sapta Andika Denpasar.” Jurnal Penelitian dan Evaluasi pendidikan Indonesia . (Online) (http://119.252.161.254/ejournal/index. php/jurnal ep/article/view/1548)

Mahardika, I.G.S. (2013). Penerapan Model Kooperatif (STAD) Meningkatkan Aktivitas Dan Hasil Belajar Tolak Peluru. Singaraja. Universitas Pendidikan Ganesha. (online) (https://ejournal. undiksha.ac.id/index.php/JJP/article/view/347) 
Pradani, W.D.E. (2015). Kemampuan Motorik Kasar Anak Tunagrahita Kelas Dasar Mampu Didik Diukur Melalui Dasar Permainan Bola Tangan Di SLB C Senuko Godean Sleman. Yogyakarta. Fakultas Ilmu Keolahragaan UNY. (online) (http://eprints.uny.ac.id/26618/)

Saputri, R.F, dkk. (2016). Model Pembelajaran Teknik Dasar Tolak Peluru Gaya Menyamping Siswa Kelas VII Di SMPN 12 Malang. Malang. Universitas Negeri Malang. (online) (http:// journal.um.ac.id/index.php/pendidikan-jasmani/ article/view/7741)

Septiyani, P. (2015). Pengaruh Aktivitas Akuatik Terhadap Kemampuan Motorik Kasar Anak Tunagrahita Ringan kelas Atas di SLB N Pembina Yogyakarta. (Online) (file:///D:/Downloads/27315513-1-SM.pdf)
Sudianto, M. (2005). Pendidikan Jasmani Kajian Teori, Praktek Pendidikan, dan Pembelajaran. Laboratorium Jurusan Ilmu Keolahragaan Universitas Negeri Malang.

Sugiono, (2016). Metode penelitian Kuantitatif, Kualitatif, dan R\&D. Bandung: Alfabeta.

Susanto, Y.D.(2015). Pengembangan Modifikasi Peluru Berbahan Dasar Serbuk Gergaji Untuk Pembelajaran Tolak Peluru Di Sekolah Dasar. Fakultas Ilmu Keolahragaan. Universitas Negeri Yogyakarta (online) (http://eprints.uny. ac.id/26572/) 